\title{
UCLA
}

Mester

Title

EI Loco

Permalink

https://escholarship.org/uc/item/7xh017cv

Journal

Mester, 11(2)

Author

Espejo-Saavedra, Fernando

Publication Date

1982

DOI

10.5070/M3112013673

Copyright Information

Copyright 1982 by the author(s). All rights reserved unless otherwise indicated. Contact the author(s) for any necessary permissions. Learn more at https://escholarship.org/terms

Peer reviewed 


\section{EL LOCO}

Con incierta proa, enfila el navío de su inquieta persona hacia Market Street o el Tenderloin. De pronto se detiene y comienza a esculpir el aire que le rodea: con las manos, con el gesto, con el cuerpo todo, que no parece que su completa humanidad sea otra cosa sino puros martillo y cincel gigantescos.

Ahora cesa en su artístico empeño; dirige unas palabras a una audiencia invisible, que debe acogerlas con gusto placentero, porque el loco, asintiendo después de su discurso, complacido sonríe.

Debe de ser un sabio; no hay que olvidar que el loco, jafortunado él!, es narrador tercero y omnisciente quien Freud no podría desposeer de nada: a saber si en alianza con misteriosos fluidos y consuelos, es el loco partícipe de un secreto de esfinge que le ha hecho dueño afortunado de un Yo integral, entero y sin fragmentos formado a la par por ojo exterior y subconsciencia.

Otra vez, inesperadamente, el loco emprende la batalla del aire. A juzgar por el empeño que pone en darle traza y forma, debe de ser el aire enemigo espantable, trasgo horripilante:

la conciencia, quizaś, que envidiosa y latente, sin tregua ni cuartel, intenta invadir los liberados espacios vitales del chalado.

Fernando Espejo-Saavedra University of California Los Angeles 